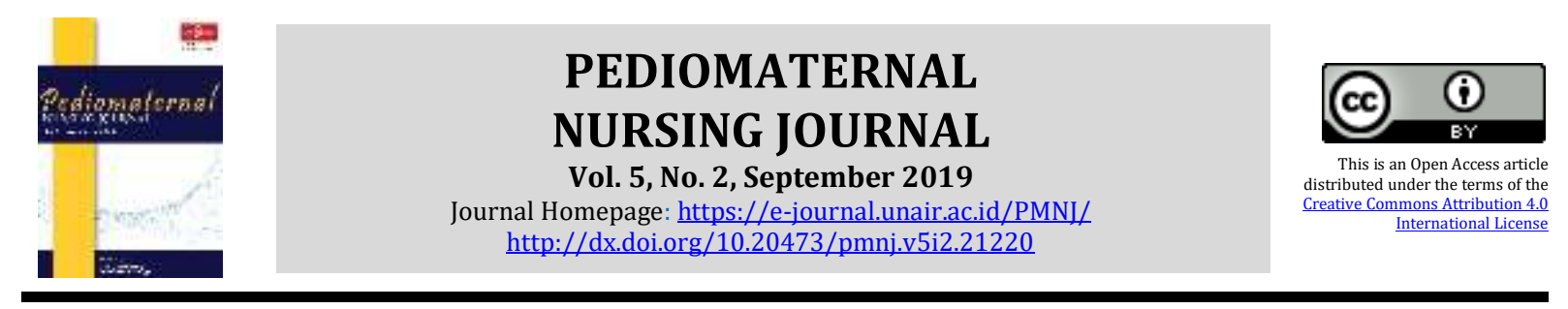

Scientific Editorial

\title{
EDITORIAL
}

\section{Upaya Bersama dalam Pencegahan Anemia Kehamilan}

\author{
Dr. Mira Triharini, S. Kp., M. Kep \\ Departemen Maternitas dan Anak, Fakultas Keperawatan, Universitas Airlangga, \\ Kampus C Mulyorejo, Surabaya, Indonesia, Telp. (031) 5913257, 5913754 Fax. (031) \\ 5913257, email: mira-t@fkp.unair.ac.id
}

Kesehatan ibu hamil merupakan hal yang sangat penting dalam siklus kehidupan perempuan. Selama masa kehamilan, setiap perempuan dapat mengalami komplikasi yang membahayakan diri maupun janinnya. Anemia pada masa kehamilan merupakan salah satu masalah kesehatan pada ibu hamil yang merupakan masalah kesehatan masyarakat dengan skala besar di tingkat dunia. Data WHO menunjukkan bahwa sekitar 38 persen ibu hamil di dunia mengalami anemia, terutama pada negara berkembang. Tingginya angka anemia pada ibu hamil memberikan kontribusi pada tingginya angka kematian ibu akibat dari perdarahan.

Penyebab dari anemia selama masa kehamilan di negara berkembang dipengaruhi oleh berbagai faktor yang meliputi defisiensi mikronutrien dari zat besi, folat, vitamin A dan B12; infeksi parasit seperti malaria dan cacingan atau infeksi kronis seperti TB dan HIV. Kontribusi dari setiap faktor penyebab anemia selama hamil akan bervariatif dipengaruhi lokasi geografis serta pola makan. Anemia selama kehamilan akan memberikan dampak buruk pada kesehatan ibu hamil dan janin. Gangguan yang dialami oleh ibu hamil tersebut berkaitan dengan masalah anemia selama hamil. Anemia pada masa kehamilan memberikan dampak pada kehamilan, persalinan dan nifas yaitu keguguran, partus prematurus, inersia uterus, partus lama, atonia uteri, syok, afribinogenemia, infeksi intrapartum dan dalam nifas, dan payah jantung. Anemia yang dialami oleh ibu hamil akan berakibat buruk pula pada bayi yaitu resiko preterm, berat badan lahir rendah dan peningkatan resiko kematian perinatal

Upaya pencegahan anemia pada masa kehamilan dapat dilakukan oleh ibu hamil dengan meningkatkan asupan zat besi melalui makanan, konsumsi pangan hewani dalam jumlah cukup dan mengurangi konsumsi makanan yang bisa menghambat penyerapan zat besi seperti: fitat, fosfat, tannin. Suplemen tablet zat besi yang diberikan minimal 90 tablet untuk memenuhi kebutuhan zat besi pada ibu hamil juga perlu untuk diminum secara tepat. Dukungan lingkungan seperti keluarga serta kelompok 
ibu hamil juga diperlukan pada upaya penurunan kejadian anemia. Dukungan sosial dari keluarga akan mempengaruhi persepsi dan keyakinan ibu hamil sehingga meningkatkan perilaku untuk mencegah anemia. Bentuk dukungan keluarga pada ibu hamil untuk mencegah anemia seperti pemberian keyakinan kemampuan ibu untuk minum tablet tambah darah secara teratur, mengingatkan untuk makan makanan bergizi, mengingatkan minum tablet tambah darah secara teratur dan keluarga memberikan contoh dengan makan makanan bergizi dan menjaga kebersihan diri. Dukungan dari sesama ibu hamil dapat diberikan selama kelas kehamilan atau menghadiri perawatan antenatal. Bentuk dukungan kelompok pada ibu hamil untuk meningkatkan perilaku pencegahan anemia seperti memberikan contoh dengan makan makanan bergizi dan minum tablet tambah darah secara teratur, serta memberikan informasi tentang cara mencegah anemia

Tenaga kesehatan memiliki peran dalam memberikan promosi kesehatan melalui pendidikan kesehatan yang tepat untuk meningkatkan pengetahuan ibu hamil tentang anemia. Teknik konseling sangat cocok dilakukan karena interaksi dalam dua arah dan dapat mengikuti kebutuhan ibu hamil. Bentuk dari dukungan tenaga kesehatan bagi ibu hamil untuk mencegah anemia adalah memberikan kesempatan pilihan pengaturan menu makanan, kesempatan menyampaikan keluhan, keyakinan akan kemampuan ibu hamil, memberikan kesempatan bertanya, dan mendengarkan cerita dari ibu hamil. Upaya dari berbagai pihak secara komprehensif dalam upaya mencegahan anemia kehamilan sangat penting untuk dilaksanakan dalam upaya menurunkan angka kejadian anemia pada ibu hamil di dunia. 